\title{
Nuclear hormone receptors in podocytes
}

\author{
Simran Khurana ${ }^{1}$, Leslie A Bruggeman ${ }^{2}$ and Hung-Ying Kao ${ }^{1 *}$
}

\begin{abstract}
Nuclear receptors are a family of ligand-activated, DNA sequence-specific transcription factors that regulate various aspects of animal development, cell proliferation, differentiation, and homeostasis. The physiological roles of nuclear receptors and their ligands have been intensively studied in cancer and metabolic syndrome. However, their role in kidney diseases is still evolving, despite their ligands being used clinically to treat renal diseases for decades. This review will discuss the progress of our understanding of the role of nuclear receptors and their ligands in kidney physiology with emphasis on their roles in treating glomerular disorders and podocyte injury repair responses.
\end{abstract}

Keywords: Glucocorticoid receptor, Mineralocorticoid receptor, Podocyte injury, Proteinuria, Focal segmental glomerulosclerosis (FSGS), Diabetic and non-diabetic nephropathy

\section{Overview}

Nuclear hormone receptors (NRs) belong to family of sequence specific and ligand activated transcription factors that both positively and negatively regulate gene expression and are involved in many developmental, cell survival, and endocrine functions in metabolism [1,2]. Consequently, aberrant NR signaling can lead to various reproductive, proliferative, and metabolic diseases. The ability of small molecule hormones to regulate NR activity make them excellent pharmaceutical targets; for example, retinoic acid (a ligand for retinoic acid receptor alpha, RAR $\alpha$ ), the synthetic antagonist tamoxifen (a ligand for estrogen receptor alpha, ER $\alpha$ ), dexamethasone (a ligand for glucocorticoid receptor alpha, GR $\alpha$ ) or thiazolidinediones (ligands for peroxisome proliferatoractivated receptor gamma, PPAR $\gamma$ ) are used in acute promyelocytic leukemia, ER $\alpha$-positive breast cancer, inflammatory disorders and type II diabetes, respectively [3]. This family of hormones also plays important roles in the kidney development, in adult renal homeostasis and in disease responses. The kidney functions in the physiologic maintenance of acid-base and salt-water balance, and in removing toxins and metabolic waste while preserving nutrients in the bloodstream. The latter filtration function is largely mediated by the glomerular

\footnotetext{
*Correspondence: hxk43@cwru.edu

'Department of Biochemistry, School of Medicine, Case Western Reserve University (CWRU) and the Comprehensive Cancer Center of CWRU, 10900 Euclid Avenue, Cleveland, Ohio 44106, USA

Full list of author information is available at the end of the article
}

podocyte, a highly differentiated kidney cell that opposes the exterior of fenestrated capillaries in the renal glomerulus. Loss or injury of podocytes results in impaired blood filtration and causes many common renal diseases characterized by nephrotic syndrome. In this review, we will discuss the roles of NRs in normal podocyte development and in glomerular diseases and their physiological hormones and synthetic ligands as potential treatments for nephrotic syndrome.

\section{Nuclear hormone receptors: classification and functional domains}

In humans, there are 48 NRs that can be broadly classified into four subfamilies based on their ligand binding, DNA binding and dimerization properties (Table 1). NRs bind to their DNA response elements either as monomers, dimers, or heterodimers. Class I receptors bind to DNA inverted repeats as homodimers, and include the estrogen receptor (ER), glucocorticoid receptor (GR), mineralocorticoid receptor (MR), progesterone receptor (PR) and androgen receptors (AR). Class II receptors bind to DNA direct repeats and heterodimerize with retinoid X receptors (RXR), and include the thyroid hormone receptors (TR), retinoic acid receptors (RAR) and retinoic X receptors (RXR), peroxisome proliferatoractivated receptors (PPAR), vitamin D3 receptors (VDR), and Liver $\mathrm{X}$ receptors (LXR). Receptors belonging to class III are known as orphan receptors since their natural ligands have not been identified. These NRs bind to the DNA direct repeats as homodimers. Class IV 
Table 1 Classification of nuclear hormone receptors

\begin{tabular}{|c|c|c|c|}
\hline Class & Nuclear Receptor & Abbreviation & Hormones and Synthetic Ligands \\
\hline \multirow[t]{5}{*}{1} & Androgen receptor & $A R$ & testosterone, flutamide \\
\hline & Estrogen receptor, alpha and beta & $E R a, \beta$ & estrogens, tamoxifen, raloxifene \\
\hline & Glucocorticoid receptor & GR & glucocorticoidl, dexamethasone, RU486 \\
\hline & Mineralocorticoid receptor & MR & aldosterone, spirolactone \\
\hline & Progesterone receptor & PR & $\begin{array}{l}\text { progesterone, medroxyprogesterone acetate, } \\
\text { RU486 }\end{array}$ \\
\hline \multirow[t]{10}{*}{ ॥ } & Constitutive and rostane receptor & CAR & androstane \\
\hline & Farnesoid $X$ receptor & FXR & bile acids, Fexaramine \\
\hline & Liver $X$ receptor, alpha and beta & $L X R a, \beta$ & oxysterols, T0901317, GW3965 \\
\hline & Peroxisome proliferator-activated receptor alpha & PPARa & fibrates \\
\hline & Peroxisome proliferator-activated receptor beta/delta & PPARß/ $/ \delta$ & fatty acids \\
\hline & Peroxisome proliferator-activated receptor gamma & PPARY & prostaglandins \\
\hline & Pregnane $X$ receptor & PXR & xenobiotics \\
\hline & Retinoid A receptor, alpha, beta and gamma & RARa, $\beta, \gamma$ & all-trans retinoic acid \\
\hline & Thyroid hormone receptor, alpha and beta & $\mathrm{TRa}, \beta, \gamma$ & thyroid hormone \\
\hline & Vitamin D receptor & VDR & vitamin D \\
\hline \multirow[t]{10}{*}{ III } & Chicken ovalbumin upstream promoter-transcription factor I & COUP-TFI & $\mathrm{n} / \mathrm{a}$ \\
\hline & Chicken ovalbumin upstream promoter-transcription factor II & COUP-TFII & $\mathrm{n} / \mathrm{a}$ \\
\hline & V-erbA-related receptor & EAR-2 & $\mathrm{n} / \mathrm{a}$ \\
\hline & Germ cell nuclear factor & GCNF & $\mathrm{n} / \mathrm{a}$ \\
\hline & Hepatocyte nuclear factor-4, alpha and gamma & HNF4a, y & Fatty acids \\
\hline & Photoreceptor cell-specific nuclear receptor & PNR & 9-cis retinoic acids \\
\hline & Retinoid $X$ receptor, alpha, beta and gamma & $\mathrm{RXRa}, \beta, \gamma$ & 9-cis retinoic acids \\
\hline & Testicular receptor 2 & TR2 & $\mathrm{n} / \mathrm{a}$ \\
\hline & Testicular receptor 4 & TR4 & $\mathrm{n} / \mathrm{a}$ \\
\hline & Homologue of the Drosophila tailless gene & TLX & $\mathrm{n} / \mathrm{a}$ \\
\hline \multirow[t]{10}{*}{ IV } & Estrogen-related receptor alpha, beta and gamma & ERRa, $\beta, \gamma$ & 9-cis retinoic acid \\
\hline & Liver receptor homolog-1 & $\mathrm{LRH}-1$ & phosphatidylinositols \\
\hline & Nerve Growth factor IB & NGFIB & $\mathrm{n} / \mathrm{a}$ \\
\hline & Neuron-derived orphan receptor 1 & NOR1 & N/As \\
\hline & Nuclear receptor related 1 & NURR1 & N/A \\
\hline & Rev-ErbA, alpha and beta & Rev-Erba, $\beta$ & heme \\
\hline & RAR-related orphan receptor, alpha, beta and gamma & $\mathrm{RORa}, \beta, \gamma$ & cholesterol, all-trans retinoic acids \\
\hline & Steroidogenic factor 1 & SF1 & phosphatidylinositols \\
\hline & $\begin{array}{l}\text { Dosage-sensitive sex reversal, adrenal hypoplasia critical region, on } \\
\text { chromosome X, gene }\end{array}$ & DAX & $\mathrm{n} / \mathrm{a}$ \\
\hline & Small heterodimer partner & SHP & $\mathrm{n} / \mathrm{a}$ \\
\hline
\end{tabular}

receptors are also orphan receptors but bind to DNA as monomers [3].

All NRs are evolutionarily related [3] and have a common modular structure consisting of four domains (Figure 1). Among these domains, the DNA binding domain (region $\mathrm{C}$ ) and the ligand binding domain (region $\mathrm{E}$ ) are the most highly conserved, whereas the N-terminal A/ $\mathrm{B}$ domain and the $\mathrm{D}$ region are comparatively less well conserved [3]. The A/B domain harbors an activation domain that stimulates transcription in a ligand-independent manner. In different NRs, both the length and the sequence of the $\mathrm{A} / \mathrm{B}$ region are variable. The central $\mathrm{C}$ domain of NRs is the evolutionarily conserved DNA binding domain. NRs bind DNA at highly specific nucleotide sequence motifs of 5-10 base pairs generally known as hormone response elements (HREs) [4-7]. The DNA 


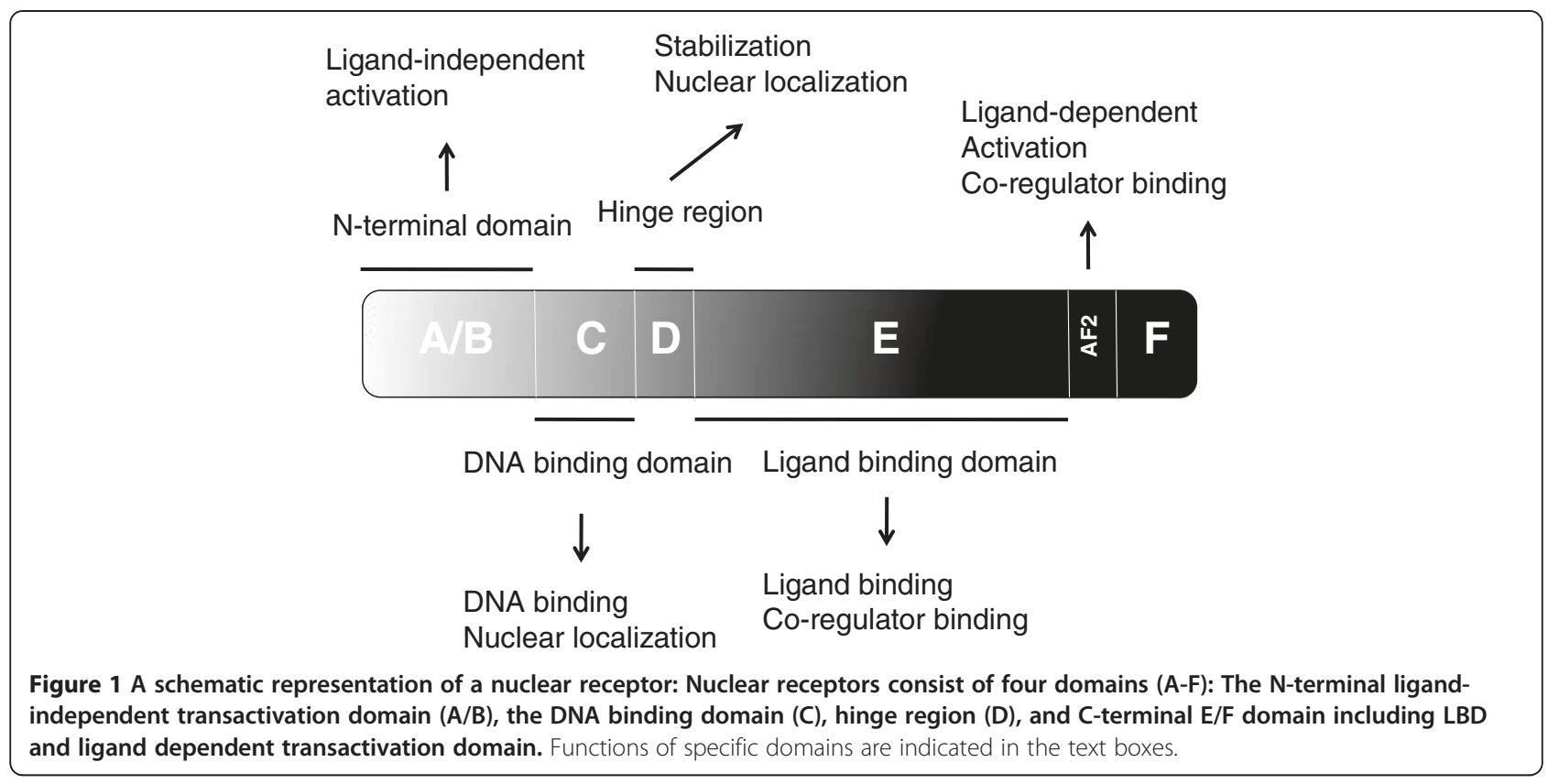

binding domain consists of two cysteine-rich zinc finger motifs, two $\alpha$-helices, and a C-terminal extension, and plays important roles in both nuclear localization and in the interaction with other transcription factors [3]. The D region serves as a linker between the DNA binding domain and the ligand-binding domain and contains a nuclear localization signal. The ligand binding domain is contained in the C-terminal $\mathrm{E}$ region and harbors four functionally interconnected regions including the ligandbinding pocket, a dimerization surface and a transcriptional co-regulator binding surface which participates in protein-protein interactions with other transcription factors, and an activation helix known as AF-2, which mediates ligand dependent transactivation [8].

\section{Mechanism of transcriptional regulation by NRs}

NRs regulate transcription through the recruitment of accessory proteins known as co-regulators (coactivators and corepressors) that dictate the transcriptional activity of the receptors. In the absence of ligand, NRs including RAR, TR, and antagonist-bound steroid receptors, recruit corepressors such as nuclear receptor corepressor (NCoR) and silencing mediator for retinoid and thyroid hormone receptors (SMRT) to inhibit transcription initiation $[9,10]$. Unliganded steroid hormone receptors such as GR, MR and ER do not normally interact with NCoR or SMRT, but interact strongly with these corepressors in the presence of antagonists [11-13]. Chromatin immunoprecipitation assays have shown that $\mathrm{N}-\mathrm{CoR}$ and SMRT complexes are recruited to NR targeted promoters [10]. Both NCoR and SMRT contain a region at their Ctermini that specifically binds to a hydrophobic groove in the surface of the ligand-binding domain of unliganded NRs. NCoR and SMRT interact with unliganded receptors through a conserved helical motif (I/L) XX (I/V) I $(\mathrm{L}=$ leucine, $\mathrm{I}=$ isoleucine, $\mathrm{V}=$ valine and $\mathrm{X}=$ any amino acid) [14-16]. Both NCoR and SMRT do not possess intrinsic enzymatic activity; however, they recruit other proteins containing histone deacetylase (HDACs) and methyltransferase (SUV39H1) activity $[17,18]$. HDACs repress transcription by deacetylating lysine residues on the $\mathrm{N}$-terminal tails of histone proteins. This condenses the chromatin, which in turn restricts access of the basic transcriptional machinery to the target promoter.

Crytallographic studies have shown that ligand binding triggers a conformational change in the ligand-binding domain of the receptor [19-23]. This conformational change is accompanied by release of the corepressor complexes and recruitment of the coactivator complexes containing histone acetyltransferase and methyltransferase activity [10] (Figure 2). Binding of these coactivators allows the subsequent recruitment of RNA polymerase II and general transcription machinery to a targeted promoter [24], thereby stimulating transcription. Structurally, helix 12 of the AF-2 region of the ligand-binding domain plays an important role in the recruitment of coactivators. Upon ligand binding, there is a reorientation of helix 12 which results in the formation of a hydrophobic groove that accommodates coactivator binding. Thus, this co-regulator exchange ultimately controls transcription through the steric opening or closing of the local chromatin structure through the modification of histone tails. 


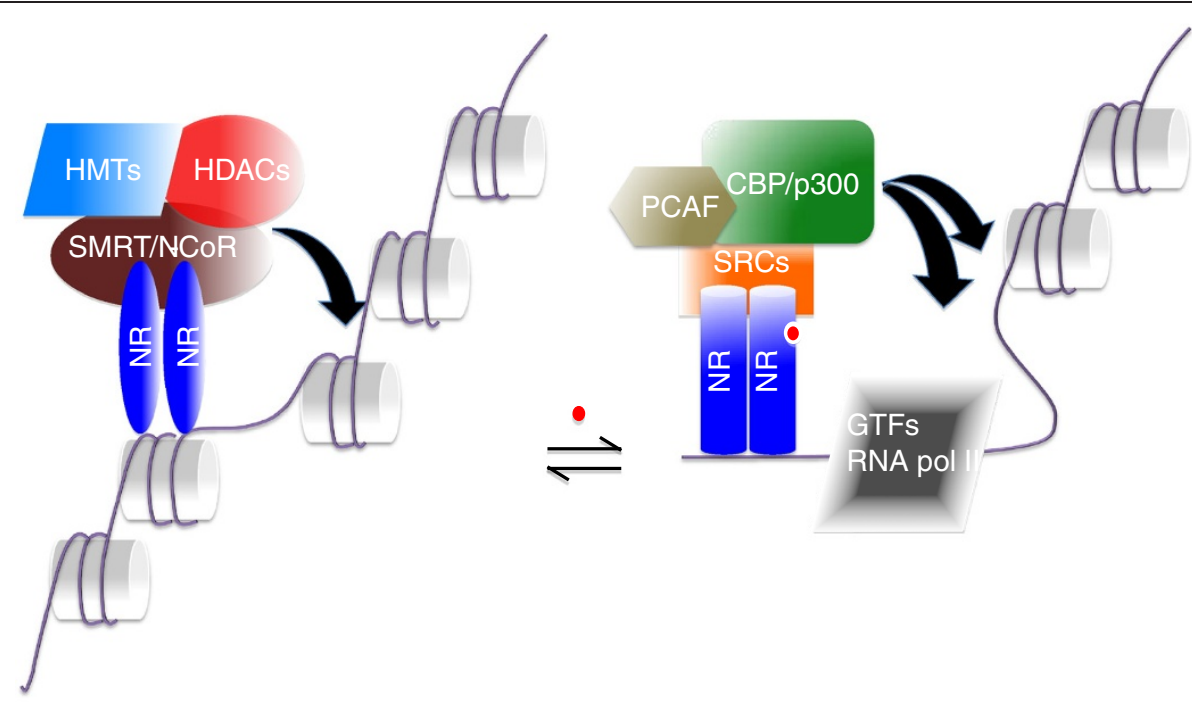

Figure 2 Ligand-dependent conformational change and transactivation of a nuclear receptor. In the absence of ligand, nuclear receptors are associated with corepressor complexes such as SMRT, HDACs and histone methyltransferases (HMTs) and inhibit transcription by keeping the chromatin tightly bound around the promoter. Ligand binding induces a conformational change in the structure of nuclear receptors which exchanges the corepressors with coactivators. The coactivators including CBP/p300, PCAF and SRCs loosen chromatin by acetylating histone tails. Acetylation of histone tails opens up the chromatin which in turn allows basal transcriptional machinery to target promoters.

\section{Significance of the LXXLL motif in coactivators in NR-mediated transcription}

Coactivators interact with NRs through the highly conserved NR interaction domain known as the NR box. The NR interaction domain consists of a short $\alpha$-helical LXXLL motif. The number of LXXLL motifs varies among different coactivators and also accounts for the preferential binding of some coactivators to a specific NR [25-29]. Among the coactivators discovered so far, the SRC (steroid receptor coactivator) family of proteins, CBP (cAMP response element-binding protein) and p300 are known for their ability to interact with and coactivate NRs [30-33]. The SRC family of coactivator consists of three family members: SRC1, the first identified nuclear receptor coactivator (also known as p160-1 and N-CoA1), SRC-2 (TIF-2, GRIP1, and N-CoA2) and SRC3 (also known as P/CIP, ACTR, AIB1, RAC3, and TRAM1) [34]. All three SRC family members share a common domain structure and have three equally spaced conserved LXXLL motifs to interact with NRs. Note that most coactivators including PCAF (p300/CBPassociated factor) independently interact with NRs and with each other. Chromatin immunoprecipitation experiments have demonstrated that these coactivators are recruited to NR targeted promoters in a sequential, cyclic manner [35]. All together, these observations suggest that SRC coactivators function by recruiting chromatin modifying enzymes to the liganded receptors on the HREs. PCAF and p300/CBP harbor potent HAT activity, while the C-termini of SRC- 1 and SRC-3 exhibit weak HAT activity [3].
Some NRs are capable of eliciting ligand-dependent transcriptional repression activity [36]. Liganded GR and TR can repress gene expression through negative response elements [37,38]. In addition, NRs such as GRs, PPARs, LXR, VDR and RAR repress NF-KB and AP-1 target gene expression in an agonist-dependent manner [39] (Figure 3). The mechanisms underlying this transrepression activity include a) competition with coactivators $[40,41]$ b) disruption of the recruitment of positive acting complexes and c) sumoylation-dependent recruitment of corepressor complexes to AP-1 and NF- $\mathrm{kB}$ targeted promoters [42]. It should be noted that many of these AP-1 and NF- $\mathrm{kB}$ target genes are key mediators of the inflammatory response.

\section{Role of NRs in glomeruli and related diseases}

While the physiological roles of NRs and their ligands have been intensively studied in cancer and metabolic syndrome $\mathrm{X}$, understanding their roles in kidney development and podocytes is still evolving. It has been a longstanding clinical practice to use NR ligands to treat kidney diseases, especially nephrotic syndrome and diseases that damage the glomerulus and podocyte, despite the lack of a clear understanding of their mechanism of action. Recent studies in multiple experimental models of renal diseases have begun to investigate the direct and indirect effects of NR in renal cells to better utilize NR ligands as therapeutic agents in common diseases such as focal segmental glomerulosclerosis (FSGS). 
A

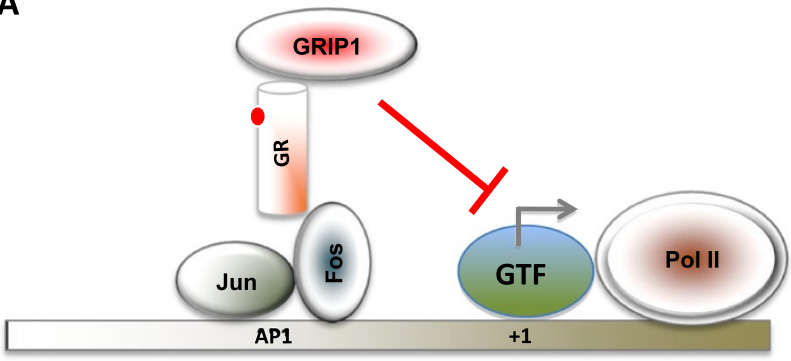

C



B

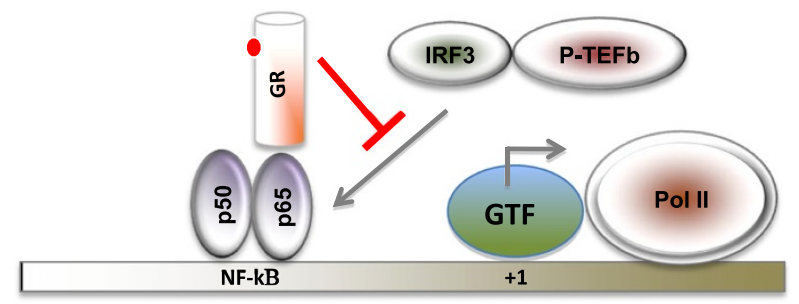

D



Figure 3 Mechanisms underlying NR-mediated transrepression. $\boldsymbol{A}$, Liganded GR binds to Fos subunit of activator protein 1 (AP-1) and represses a subset of AP-1-dependent genes through GR interacting protein 1(GRIP-1). $\boldsymbol{B}$. Liganded GR binds to p65 subunit of nuclear factor-KB (NF-KB) and prevents the binding of interferon regulatory factor 3 (IRF3) or positive transcription elongation factor b (P-TEFb) to the promoter of some NF-KB target genes. $\boldsymbol{C}$, Liganded GR binds to Fos subunit of AP-1 and represses a subset of AP-1 dependent genes through nuclear thyroid receptor interactor 6 (NTRIP6). D, Liganded PPARY (or LXR) is posttranslationally modified by Sumo1 (or Sumo2) conjugation, which facilitates an interaction with nuclear receptor corepressor (NCoR) complex to inhibit the recruitment of ubiquitin-conjugating enzymes and 195 proteasome components (not shown) required for the degradation of NCoR. Transcription start site is shown as +1 . GTF refers to the general transcription factors. Pol II refers to RNA polymerase II. This figure is adopted from Glass and Saijo (42).

\section{Podocytes - terminally differentiated cells critical for kidney filtration function}

One of the key functions of the kidney is to filter the blood, removing catabolic byproducts that can become toxic if not eliminated. The filtration apparatus of the kidney is the glomerulus, a tuft of capillaries, consisting of three components: the fenestrated glomerular endothelium, the glomerular basement membrane, and a visceral epithelium also known as the podocyte. Podocytes cover the exterior of the capillary and attach to the outer layer of the glomerular basement membrane. They form novel marcromolecular structures that function like a molecular sieve, allowing high volume fluid flow while preventing passage of blood cells and large serum proteins such as albumin from entering the urine. Podocytes also contribute significantly to the formation of the glomerular basement membrane and the integrity of the vascular endothelium. Thus, podocyte damage is a hallmark of nephrotic syndrome characterized by severe proteinuria (protein in the urine) and hypoalbuminemia (low levels of blood albumin).
Podocytes are highly specialized terminally differentiated cells that extend numerous lamellipodia that branch into primary and secondary processes, which further ramify into smaller processes known as foot processes [43]. The latter are composed of highly ordered parallel contractile actin filament bundles $[44,45]$. Foot processes from neighboring cells interdigitate and are connected by a modified adherent junction called slit diaphragms that span a $30-50 \mathrm{~nm}$ wide intercellular space that provides for the passage of fluid. The slit diaphragm of podocytes is composed of the extracellular domains of a number of transmembrane proteins such as nephrin, Neph-1, P-cadherins and FAT [45] (Figure 4). The ability of podocytes to act as a filtration barrier depends on the integrity of the slit diaphragm [43]. Recent studies have indicated that the components of foot processes not only serve as a structural barrier; they also respond to and mediate extracellular signaling events and are indispensable for proper physiological responses of the podocyte to the environment [46]. 


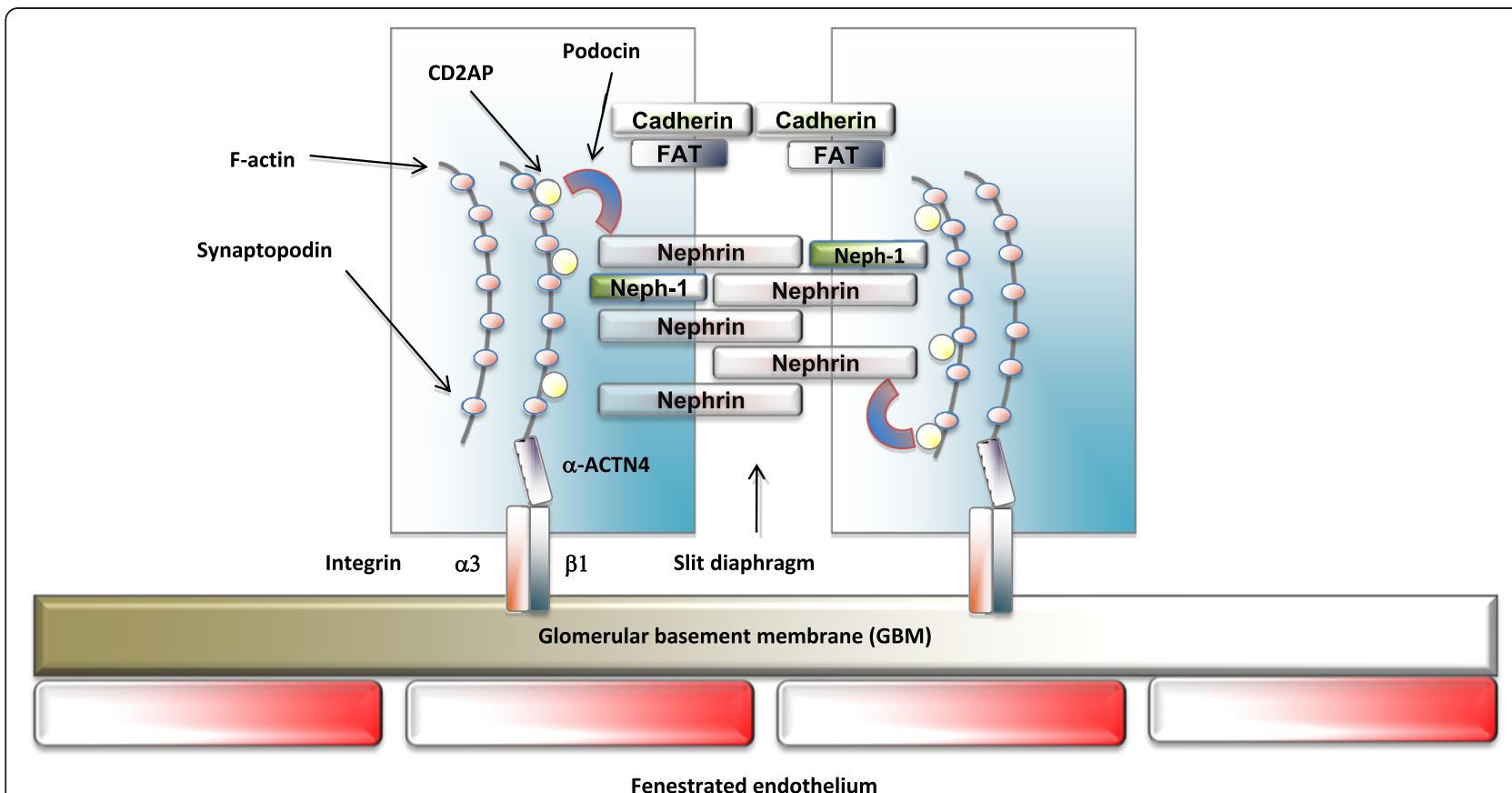

Figure 4 The structure of podocyte. The glomerular capillary wall consists of a fenestrated endothelium, a basement membrane and podocyte foot processes. The foot processes form the filtration slits and are spanned by slit diaphragms. The slit diaphragm is composed of the extracellular domains of a number of unique transmembrane proteins such as Nephrin, Neph-1, P-cadherins and FAT.

\section{Focal segmental glomerulosclerosis}

Focal segmental glomerulosclerosis is common pathological condition consisting of local and sectional degeneration and scarring within the glomerular tuft. It occurs in many inherited and acquired kidney disease, and is frequently a consequence of direct podocyte injury. Upon injury, the podocyte responds with cytoskeletal reorganization and ultimately the foot processes become disorganized. At the molecular level, podocyte injury is associated with 1) increased reactive oxygen species (ROS) and endoplamic reticulum (ER) stress, 2) aberrant activation of mammalian target of rapamycin (mTOR), Wnt and transforming growth factor beta (TGF- $\beta$ ) signaling, 3) activation of small GTPase RhoA and 4) decreased expression of slit diaphragm components such as nephrin [47]. Any type of oxidative or inflammatory stress leading to effacement of podocyte foot processes further deteriorates the filtration barrier and overall kidney function, and eventually results in renal failure. Genetic studies have identified mutations in many known podocyte structural proteins such as the slit diaphragm components nephrin, CD2 associated protein (CD2AP), transient receptor potential cation channel, subfamily C, member 6 (TRPC6) and podocin or in proteins regulating actin dynamics including alpha actinin 4 (ACTN4) and inverted formin 2 (INF2) as being tightly linked to FSGS. Animal studies confirm that knock-in of diseaseassociated mutations or podocyte-specific gene deletions leads to FSGS. These studies highlight the important role of the slit diaphragm and actin architecture in the integrity of podocytes. A reverse correlation between the degree of proteinuria and nephrin expression levels has also been documented [48-50]. Furthermore, mutations in the ACTN4 and synaptopodin promoters have been found in patients and these mutations are associated with reduced promoter activity [51], suggesting that loss of nephrin, ACTN4 or synaptopodin expression may contribute to FSGS. These findings further imply suggest that mis-regulation of transcriptional networks controlling slit diaphragm component gene expression can contribute to podocyte disorders. Alternatively, focal segmental glomerulosclerosis can be caused secondarily from metabolic or immunologic dysfunction that also leads to podocyte injury and proteinuria [52,53].

\section{NRs in podocyte pathophysiology}

To date, there are no known mutations in NRs that are linked to familial forms of focal segmental glomerulosclerosis and nephrotic syndrome. However, clinical evidence and mouse genetic studies have implicated several NRs in contributing to podocyte development and disease (Table 2). Among the known NRs, the mineralocorticoid receptor (MR) and its agonists have been strongly associated with proteinuria [54,55]. Recent studies from animals and cultured human or mouse podocytes indicate that synthetic hormones for class I and II NRs 
Table 2 A summary of the physiological function of nuclear hormone receptors in podocytes

\begin{tabular}{clll}
\hline Nuclear receptor & \multicolumn{1}{c}{ Role in kidney function/disease } & Reference \\
\hline Estrogen receptor & renoprotective blocks podocyte apoptosis & [61-64] \\
Glucocorticoid receptor & well-known renoprotective functions of GR ligands & {$[56,65-67]$} \\
Mineralocorticoid receptor & renoprotective when suppressed & {$[68-74]$} \\
Peroxisome proliferator-activated receptor-a & renoprotective enhances Nephrin expression & {$[75-78]$} \\
Peroxisome proliferator-activated receptor- $\gamma$ & renoprotective blocks podocyte apoptosis blocks podocyte hypertrophy/proliferation & {$[79-82]$} \\
Retinoic acid receptor-a & renoprotective enhances podocyte differentiation & [83-90] \\
Vitamin D receptor & reduces renal inflammation enhances Nephrin expression & [91-95] \\
\hline
\end{tabular}

including estradiol, glucocorticoid, retinoid, pioglitazone, vitamin D3 and WY-14643 protect or rescue podocytes from experimental injury [56-60]. Post treatment of injured podocytes with ligands for the above-mentioned NRs restores cytoskeletal architecture and enhances expression of nephrin. A unified theme derived from clinical, animal and cell culture studies suggest that NRs, except MR, elicit renoprotective activity by inhibiting apoptosis, by acting as antioxidants and by enhancing/ restoring nephrin expression.

\section{Class I NRs}

Class I NRs including MR, GR, ER, PR and AR bind to the DNA inverted repeats (IRs) as homodimers (Table 1). Among these, MR and GR are the best studied in the kidney due to the early cloning of their genes and discovery of their physiological ligands. Furthermore, recently the physiological importance of ER in kidney pathophysiology has emerged.

\section{MR (mineroglucocorticoid receptor)}

MR function in the kidney has been studied extensively focusing on its roles in controlling blood pressure and salt and water balance, functions primarily associated with the renal tubule not glomerulus. Consequently, the renally important MR ligand, aldosterone, is well-known to be involved in renal disease and pathology, and MR antagonists are used extensively in treating hypertension [68]. MR is normally expressed in many cells of the kidney, not just tubular epithelia, but also glomerular mesangial cells and podocytes $[69,70,96]$. Studies in various animal models have therefore also linked MR function to mesangial cell proliferation and podocyte injury and proteinuria [69,97-99]. Recent studies have identified podocytes as a direct target of aldosterone through the MR [55,69,71]. MR blockade with eplerenone (an antagonist of MR) reduces podocyte injury and proteinuria and induces podocin and nephrin expression in podocyte in type 1 and type 2 diabetic animal models [72,73,100]. By contrast, chronic infusion of aldosterone induces hypertension with massive proteinuria and glomerular podocyte injury in uninephrectomized (surgical excision of one kidney) rats [69]. Furthermore, the induced podocyte injury is associated with significantly reduced nephrin and podocin expression [101]. In addition, treatment with the MR antagonist eplerenone significantly decreased podocyte injury and proteinuria in rodent models of hypertensive glomerulosclerosis [68,74].

The mechanisms by which aldosterone induces proteinuria are likely complex. However, the observation that podocytes express MR suggests a direct role of liganded MR in podocyte injury. In podocytes, aldosterone treatment induces nuclear translocation of MR, activation of reduced nicotinamide adenine dinucleotide phosphate (NADPH) oxidase, and accumulation of ROS. Additionally, aldosterone increases expression of an oxidative stress effector kinase, Sgk1, and significantly delays wound- healing and promotes apoptosis in cultured mouse podocytes [69]. Taken together, these data suggest that some of the aldosterone-induced proteinuric effects and podocyte damage are derived from increases in oxidative stress in podocytes. Consistent with this hypothesis, the antioxidant tempol markly attenuates podocyte injury and proteinuria in aldosterone-infused rats and other rodent models of glomerulosclerosis. In addition to podocytes, MR is expressed in vascular endothelial and smooth muscle cells in the glomeruli, suggesting that $\mathrm{MR}$ action in these cells may also play a role in glomerular podocyte injury. Taken together, MR and its agonists are critical mediators of podocyte injury under several pathological conditions.

\section{GR (glucocorticoid receptor)}

Glucocorticoid therapy is a mainstay treatment option for many forms of nephrotic syndrome. However, the mechanisms by which the glucocorticoids as GR ligands ameliorate proteinuria and inflammation-associated glomerular disease are not completely understood.

All cell types in the glomerulus express GRs [102]. Both glucocorticoid inactivating enzyme (11 $\beta$-hydroxysteroid dehydrogenase type II) and GR are expressed in podocytes [103]. Moreover, cultured podocytes also 
express the key components of the GR-mediated signaling pathway including HSP90 and the immunophilins FKBP51 and FKBP52 [103]. Data, including our unpublished results, demonstrate that the glucocorticoid dexamethasone treatment alters gene expression patterns of cultured podocytes following either short-term highdose treatment or long-term low-dose treatment [103]. These observations indicate that podocytes are a major target cell type for the action of glucocorticoids.

Several mechanisms accounting for the renoprotective of GR ligands effect include: 1) protecting podocytes from endoplasmic reticulum stress and rescuing a nephrin trafficking defect due to decreased N-linked glycosylation in the endoplasmic reticulum [60], 2) restoring or protecting cytoskeletal architecture by upregulating nephrin expression $[65,66], 3)$ inhibiting puromycin aminonucleoside (PAN)-induced reduction of phosphorylated Erk2 [67] and 4) suppressing expression of NF-kB-dependent cytokines such as IL-6 and IL-8 [65] by transrepression of NF- $\kappa B$. While the GR ligands possess several renoprotective effects in glomeruli, steroid-resistance and systemic toxicity remain major issues for their long-term use. A better understanding of the mechanisms by which GR and the glucocorticoids control gene regulatory network and their crosstalk with other signaling pathways in podocytes will ensure optimal therapeutic benefits of steroid treatment.

\section{ER (estrogen receptor)}

Podocytes express both ER $\alpha$ and ER $\beta$ [61]. Estrogens are protective against podocyte injuries in vitro and in vivo. First, it has long been noted that women have a better prognosis in some chronic kidney disorders than men, suggesting that gender-specific hormones play a role in glomerular development and related diseases. Second, in animal models, estrogen shows beneficial effects and protects podocytes from injury in a model of spontaneous progressive kidney disease [62] and type 2 diabetes [63]. Third, ER $\alpha$ knockout mice are more susceptible to the development of glomerulosclerosis and show reduced expression of desmin and nephrin [64]. Furthermore, ER $\alpha$ mediates estrogen protective effects from PAN-induced podocyte apoptosis both in vitro and in vivo [61]. Finally, it was recently demonstrated that ER $\alpha$-mediated protective effects are associated with stabilization of mitochondrial membrane potential and activation of mitogen activated protein kinase 12 (MAPK) [61]. As ER emerges as a critical signaling molecule in the podocytes, more findings on its roles in protecting podocytes will likely surface; especially regarding its roles controlling transcriptional regulatory networks and mitogenic effects.

\section{Class II NRs}

Class II NRs bind to HREs with direct repeats (DRs) and heterodimerize with the common partner, RXR. Class II NRs include the TRs, LXRs, RARs, RXRs, VDR, PPARs (Table 1). These NRs were considered orphan receptors until the discovery of their physiological ligands in the early 1990s. In fact, the anti-diabetic thiazolidinediones were in clinical use long before their mechanism of action as high affinity PPARy ligands was identified [79].

\section{PPARs}

There are three subtypes of PPAR $(\alpha, \beta / \delta$ and $\gamma)$ in both humans and rodents [104]. All three PPARs are expressed in the kidney and are known to play important roles in renal pathophysiology $[105,106]$. These receptors are major sensors for fibrates, polyunsaturated fatty acids and 15d-prostaglandin $\mathrm{J} 2$ and are involved in lipid metabolism and fatty acid oxidation in many tissues.

Several reports have indicated that agonists of PPAR $\alpha, P P A R \beta / \delta$ and PPAR $\gamma$ alleviate renal damage associated with ischemia/reperfusion injury in rats $[75,76,80,81,107]$. This renoprotective activity is associated with maintenance of nephrin and pro-survival gene expression. In another model, the anthracycline antibiotic drug doxorubicin exhibits cytotoxic effects on several organs including kidney. Doxorubicin induces renal injury by causing effacement of podocyte foot processes. Treatment of these mice with the PPAR $\alpha$ ligand fenofibrate partially alleviates these nephritic symptoms through restoration of nephrin expression and protecting podocytes from apoptosis [77]. Predictably, PPAR $\alpha$ knockout mice exhibit accelerated doxorubicin-induced kidney injury, diabetic nephropathy and severe proteinuria [77]. In fact, PPAR $\alpha$ activation in podocytes resulted in an increase in nephrin expression by stimulating nephrin promoter activity, stabilizing nephrin mRNA and blocking apoptotic signaling [58,78]. PPAR ligands potently inhibit expression of proinflammatory cytokines including vascular cell adhesion molecule (VCAM-1) and IL-6 expression in various cell types $[108,109]$ and reduce lipopolysaccharide (LPS)induced activation of NF- $\mathrm{kB}$ in a PPAR $\gamma$-dependent pathway in human kidney-2 (HK-2) cells [110]. Intriguingly, an increase in PPARy expression has been observed in both rat and human kidney sclerotic conditions in vivo, suggesting a compensatory regulatory role of PPAR $\gamma$ in response to podocyte injury. In vitro data has also indicated that PPAR $\gamma$ activation protects against PAN-induced apoptosis and necrosis of podocytes [82]. In summary, the ability of PPAR agonists to protect or rescue podocytes from injury is attributed to their ability to enhance expression of slit diaphragm components such as nephrin and inhibit pro-inflammatory genes. The fact that PPARs and their ligands play key roles in lipid and cholesterol metabolism and fatty acid oxidation suggest a link between their 
ability to protect podocytes from injury and these metabolites and podocyte development and pathology. This will help rationalize the use of PPAR ligands in the treatment of podcoyte diseases.

\section{RARs}

The retinoids, major ligands of the RARs, are well known developmental morphogens, important for cell specification and pattern formation in the development of many organs including limbs, lung, and kidney [111]. Vitamin A deficiency and mutations of RARs cause abnormalities in fetal kidneys, indicating that vitamin A and its receptors are essential for normal kidney development [83]. Similarly, RAR $\alpha$-deficient mice exhibit abnormalities in fetal kidney development and a reduced number of nephrons, the major structural and functional unit of the kidney [84].

In multiple experimental models of kidney diseases including PAN-induced nephropathy, mesangioproliferative glomerulonephritis, lupus nephritis, and diabetic nephropathy all-trans retinoic acid, the vitamin A active metabolite, has been shown to be renoprotective. Alltrans retinoic acid alleviates PAN-induced proteinuria and the effacement of podocyte foot processes. In addition, administration of all-trans retinoic acid prior to PAN treatment protects animals from proteinuria and podocyte injury [85]. Consistent with this observation, recovery from PAN-induced nephropathy is significantly delayed in animals fed with a vitamin A-deficient diet $[59,85]$. In streptozotocin-induced diabetic and antiThy1.1 antibody-induced nephritis rats, retinoic acid markedly protected animals from proteinuria and renal injury. Furthermore, activation of RARs by selective ligands prevents oxidative stress-induced apoptosis in podocytes and mesangial cells [86].

In a unique class of renal disease characterized by podocyte dedifferentiation and proliferation, HIVassociated nephropathy and the collapsing glomerulopathies, the expression of retinol dehydrogenase type 1 and 9, two key enzymes in retinoic acid biosynthesis, and the overall enzymatic activity for retinoic acid synthesis were markedly reduced, suggesting that endogenous retinoic acid synthesis is impaired in diseased kidneys [87]. In a mouse model of HIV-associated nephropathy, Am580 and BD4, water-soluble RAR $\alpha$-specific agonists, protected animals from proteinuria, glomerosclerosis, and podocyte proliferation, and restored podocyte differentiation markers $[88,89]$. This is consistent with data from the knockout mouse of RAR $\alpha$, which leads to more aggressive kidney disease. Indeed, retinoids are known to inhibit glomerular proliferation and ameliorate glomerular lesions and proteinuria in established models of renal damage [39]. Activated RAR $\alpha$ signaling slows the progression of kidney disease possibly by preserving the quiescent, highly differentiated state of the podocyte. As such, specific activation of the RAR $\alpha$ can be considered a promising therapeutic strategy for patients with renal diseases associated with abnormal proliferation and cellular dedifferentiation.

As mentioned earlier, proteinruia in diabetic and nondiabetic diseases is associated with reduced podocyte expression of nephrin and podocin. All-trans retinoic acid protected podocytes from injury and enhanced nephrin and podocin expression in vitro and in vivo $[90,112]$. The promoter of the human and mouse nephrin gene (NPHS1) contains three putative retinoic acid response elements (RAREs) [59,66] and all-trans retinoic acid enhances nephrin promoter activity in a dose-dependent manner. However, there is no evidence demonstrating that RARs or RXRs directly target the putative RAREs in primary or cultured podocytes. In vitro, all-trans retinoic acid inhibits HIV-induced podocyte proliferation and restores podocyte differentiation markers. Although the exact mechanisms underlying the ability of all-trans retinoic acid to inhibit apoptosis remain unclear, suppression of a cell death pathway mediated by JNK and activator protein -1 (AP-1) has been proposed [85]. In cultured podocytes, high glucose rapidly up-regulates the monocyte chemoattractant peptide (MCP-1) mRNA transcript and protein release; however, treatment with all-trans retinoic acid suppresses MCP-1 transcription, and significantly inhibits high glucose-induced MCP-1 protein synthesis [113]. Another study demonstrated that retinoids slow down progression of renal disease by suppressing important mediators such as angiotensin II, endothelin and TGF- $\beta$ in an anti-Thy1.1 nephritis rat model [114]. Moreover, recent studies have indicated that retinoids suppress NF- $\mathrm{kB}$ and AP-1 in non-diabetic nephropathy $[115,116]$. Thus, RARs may have additional renoprotective functions through the transcriptional control of podocyte-specific proteins and pro-inflammatory cytokines that are know to further escalate pathogenic cascades in the kidney.

Because all-trans retinoic acid is renoprotective in animal studies, a phase II clinical study has been approved for the use of all-trans retinoic acid to treat patients with steroid-resistant minimal change diseases including focal segmental glomerulosclerosis and collapsing glomerulopathy (ClinicalTrials.gov Identifier NCT00098020). Therefore, a complete understanding of the mechanisms underlying ATRA- and RAR-mediated renoprotective activity will further support the use of all-trans retinoic acid and the development of additional RAR agonists for the treatment of kidney disorders.

\section{VDR}

Vitamin D deficiency is associated with proteinuria [117] and is commonly found in type 1 and type 2 diabetic 
patients [117-122]. These observations suggest that decreased vitamin D3 may contribute to increased risk of diabetes complications and mortality and imply an intrinsic anti-proteinuric activity for vitamin D. In fact, treatment with doxercalciferol, a VDR agonist, alleviates proteinuria and glomerulosclerosis in type 1 and type 2 diabetic animals [121,123] and prevents diet-induced obesity and insulin resistance. VDR agonists also protect animals in non-diabetic models of renal disease, including Heyman Nephritis [124], an anti-thy-1 model of mesangial proliferative glomerulonephritis [125-127], subtotal nephrectomy-associated podocyte loss and hypertrophy $[128,129]$, PAN- or adriamycin-induced podocyte apoptosis and loss [130,131], unilateral ureteral obstruction [91] and X-linked Fabry disease-associated proteinuric renal injury [132].

Similar to ER $\alpha$ and RAR $\alpha$ knockout mice, VDR knockout mice are more susceptible to diabetic kidney injury $[92,133]$ and streptozotocin-induced diabetic kidney disease. VDR is expressed in glomerular podocytes, as well as other cell types in the glomerulus and in the tubular epithelium [134]. Using 14C-labelled vitamin D3, it was found that 1,25-(OH)2-vitamin D3 localizes in the nucleus of podocytes, suggesting a regulatory action of the VDR and vitamin D3 in these cells [134]. Treatment of diet-induced obese mice with the VDR agonist, paricalcitol, has been shown to decrease proteinuria, and podocyte injury. The same agonist also reduces proteinuria in diabetic nephropathy [132], in part by interrupting the damaged pathway initiated by lysoglobotriaosylceraminde in podocytes.

VDR appears to be highly inducible in podocytes [93], suggesting that podocytes are a main target of vitamin D3. Renal injury is accompanied by significant upregulation of $\beta$-catenin, predominantly in podocytes and tubular epithelial cells. The VDR agonist, paricalcitol, induces a physical interaction between the VDR and $\beta$-catenin in podocytes, thereby suppressing of $\beta$-cateninmediated gene transcription. Other studies have suggested that vitamin D3 elicits its anti-apototic and pro-survival response in podocytes through suppression of caspase- 3 activity, TGF- $\beta 1$ signaling and the expression of several apoptosis related proteins (Fas, FADD and Bax). Vitamin D3 also increases anti-apoptotic protein expression and activates bone morphogenetic protein 7 (BMP-7) signaling. The ability of vitamin D3 to block high glucose-induced angiotensinogen through inactivation of NF- $\mathrm{kB}$ activity has also been proposed [135]. In addition, 1,25(OH)2D3 and its analogs also induce nephrin mRNA and protein expression $[66,136]$. A mechanism by which $1,25(\mathrm{OH}) 2 \mathrm{D} 3$ induces association of VDR with its response elements in the nephrin promoter and the recruitment of RNA polymerase II and histone H4 acetylation has been proposed [94]. Similar observations have shown that $1,25(\mathrm{OH}) 2 \mathrm{D} 3$ reverses high glucoseinduced nephrin reduction in podocytes and prevents nephrin decline in both type 1 and 2 diabetic mice [95].

In summary, a body of evidence indicates that VDR and its agonists are capable of eliciting renoprotective effects through enhancing/maintaining nephrin expression and inhibiting injurious pathways to podocytes. This suggests that VDR ligands may be promising therapeutic agents to prevent/ameliorate glomerulopathy.

\section{Concluding remarks}

NRs control many aspects of cell differentiation, animal development and homeostasis. Some NR ligands have proven beneficial in treating human diseases including cancer, inflammatory disease and metabolic syndrome. However, our understanding of NR function in podocytes is still at an early stage, in part, due to lack of knowledge of their target genes. We know how NR functions in other tissues and cell types and how they crosstalk with other signaling pathways. For example, in addition to ligand-dependent activation of their target genes, NRs such as GR, PPAR, VDR and RAR possess ligand-dependent transrepression activity that inhibits NF- $\mathrm{kB}$ and AP-1 [42], and liganded PPARs and TR have been shown to crosstalk with mTOR signaling $[137,138]$. Are these mechanisms conserved in podocytes? Given the facts that TNF $\alpha$ and IL- $1 \beta$, both of which are NF- $\mathrm{kB}$ activating agents, decrease nephrin expression, this question is highly relevant to NR action in podocytes. Are there cell type-specific functions of NRs present in podocytes? Studies on conditional and podocyte-specific knockout animals of NRs will likely provide a better understanding of the role of a given NR in podocyte development. Currently, only a handful of NRs has been studied in podocytes. It is certain that NRs not discussed in this review will also have important roles in podocyte development and related disorders. Lastly, cell-cell interactions between podocytes and glomerular endothelial cells are also critical to podocyte development and maintenance of the filtration barrier integrity. As such, NR function in glomerular endothelial cells will be equally important to explore.

\footnotetext{
Abbreviations

AP-1, Activator protein -1; ATRA, All-trans retinoic acid; ACTN4, Alpha actinin 4; BMP-7, Bone morphogenetic protein 7; CBP, CAMP response elementbinding protein; CD2AP, CD2 associated protein CD2AP; DR, Direct repeats $\mathrm{DR}$; ERa/ $\beta$, Estrogen receptor alpha/beta; FKBP, FK506 Binding Protein; FSGS, Focal segmental glomerulosclerosis; GRa, Glucocorticoid receptor alpha; HSP90, Heat shock protein 90; HAT, Histone acetylase; HDAC, Histone deacetylase; HRE, Hormone response binding element; HK-2, Human kidney2; INF2, Inverted forming-2; IR, Inverted repeats; LPS, Lipopolysaccharide; LXR, Liver X receptor; mTOR, Mammlian target of rapamycin;

$M R$, Mineralocorticoid receptor; MAPK, Mitogen activated protein kinase; MCP-1, Monocyte chemoattractant peptide; NF-kB, Nuclear factor kappa B; $\mathrm{NR}$, Nuclear receptor; NCoR, Nuclear receptor corepressor; PCAF, p300/CBPassociated factor; PPAR/ $/ \beta / \gamma$, Peroxisome proliferator-activated receptor; PR, Progesterone receptor; PAN, Puromycin aminonucleoside; RARa, Retinoic
} 
acid receptor alpha; RARE, Retinoic acid response element; RXR, Retinoid X receptor; sgk1, Serine/threonine-protein kinase 1; SMRT, Silencing mediator for retinoid and thyroid hormone receptors; SRC, Steroid receptor coactivator; TR, Thyroid hormone receptor; TGF- $\beta$, Transforming growth factor $\beta$; VCAM, Vascular cell adhesion molecule; VDR, Vitamin D3 receptor.

\section{Competing interests}

The authors declare that they have no competing interest.

\section{Authors' contributions}

SK and HYK drafted and LB edited the manuscript text, figures and tables. All the authors read and approved the final manuscript.

\section{Acknowledgement}

We thank Dr. David Samols for his comments on the manuscript. H.-Y. Kao is supported by NIH, R01 DK078965 and HL093269.

\section{Author details}

'Department of Biochemistry, School of Medicine, Case Western Reserve University (CWRU) and the Comprehensive Cancer Center of CWRU, 10900 Euclid Avenue, Cleveland, Ohio 44106, USA. ${ }^{2}$ Rammelkamp Center for Education and Research and Department of Medicine, MetroHealth Medical Center, Case Western Reserve University School of Medicine, Cleveland, Ohio, USA

Received: 6 June 2012 Accepted: 10 August 2012

Published: 20 September 2012

\section{References}

1. Mangelsdorf DJ, Thummel C, Beato M, Herrlich P, Schutz G, Umesono K, Blumberg B, Kastner P, Mark M, Chambon P, et al: The nuclear receptor superfamily: the second decade. Cell 1995, 83(6):835-839.

2. Francis GA, Fayard E, Picard F, Auwerx J: Nuclear receptors and the control of metabolism. Annu Rev Physiol 2003, 65:261-311.

3. Germain P, Staels B, Dacquet C, Spedding M, Laudet V: Overview of nomenclature of nuclear receptors. Pharmacol Rev 2006, 58(4):685-704.

4. Luisi B, Freedman L: Nuclear receptors. Dymer, dymer binding tight. Nature 1995, 375(6530):359-360.

5. Luisi BF, Schwabe JW, Freedman LP: The steroid/nuclear receptors: from three-dimensional structure to complex function. Vitam Horm 1994, 49:1-47.

6. Schwabe JW: Transcriptional control: how nuclear receptors get turned on. Curr Biol 1996, 6(4):372-374

7. Schwabe JW, Teichmann SA: Nuclear receptors: the evolution of diversity. SCi STKE 2004, 2004(217):pe4.

8. Warnmark A, Treuter E, Wright AP, Gustafsson JA: Activation functions 1 and 2 of nuclear receptors: molecular strategies for transcriptional activation. Mol Endocrinol 2003, 17(10):1901-1909.

9. Lavinsky RM, Jepsen K, Heinzel T, Torchia J, Mullen TM, Schiff R, Del-Rio AL, Ricote M, Ngo S, Gemsch J, et al: Diverse signaling pathways modulate nuclear receptor recruitment of $\mathrm{N}-\mathrm{CoR}$ and SMRT complexes. Proc Natl Acad Sci U S A 1998, 95(6):2920-2925.

10. Shang Y, Hu X, DiRenzo J, Lazar MA, Brown M: Cofactor dynamics and sufficiency in estrogen receptor-regulated transcription. Cell 2000, 103(6):843-852.

11. Vegeto E, Allan GF, Schrader WT, Tsai MJ, McDonnell DP, O'Malley BW: The mechanism of RU486 antagonism is dependent on the conformation of the carboxy-terminal tail of the human progesterone receptor. Cell 1992, 69(4):703-713

12. Zhang $\mathrm{X}$, Jeyakumar M, Petukhov S, Bagchi MK: A nuclear receptor corepressor modulates transcriptional activity of antagonist-occupied steroid hormone receptor. Mol Endocrinol 1998, 12(4):513-524.

13. Fisher $C L$, Pineault $N$, Brookes $C$, Helgason $C D$, Ohta H, Bodner $C$, Hess JL, Humphries RK, Brock HW: Loss-of-function Additional sex combs like 1 mutations disrupt hematopoiesis but do not cause severe myelodysplasia or leukemia. Blood 2010, 115(1):38-46.

14. Hu X, Lazar MA: The CoRNR motif controls the recruitment of corepressors by nuclear hormone receptors. Nature 1999, 402(6757):93-96.
15. Nagy L, Kao HY, Love JD, Li C, Banayo E, Gooch JT, Krishna V, Chatterjee K, Evans RM, Schwabe JW: Mechanism of corepressor binding and release from nuclear hormone receptors. Genes Dev 1999, 13(24):3209-3216.

16. Perissi V, Staszewski LM, McInerney EM, Kurokawa R, Krones A, Rose DW, Lambert MH, Milburn MV, Glass CK, Rosenfeld MG: Molecular determinants of nuclear receptor-corepressor interaction. Genes Dev 1999, 13(24):3198-3208.

17. Hayakawa T, Nakayama J: Physiological roles of class I HDAC complex and histone demethylase. J Biomed Biotechnol 2011, 2011:129383.

18. Cunliffe VT: Eloquent silence: developmental functions of Class I histone deacetylases. Curr Opin Genet Dev 2008, 18(5):404-410.

19. Renaud JP, Rochel N, Ruff M, Vivat V, Chambon P, Gronemeyer H, Moras D: Crystal structure of the RAR-gamma ligand-binding domain bound to all-trans retinoic acid. Nature 1995, 378(6558):681-689.

20. Bourguet W, Germain P, Gronemeyer H: Nuclear receptor ligand-binding domains: three-dimensional structures, molecular interactions and pharmacological implications. Trends Pharmacol Sci 2000, 21(10):381-388.

21. Bourguet W, Vivat V, Wurtz JM, Chambon P, Gronemeyer H, Moras D. Crystal structure of a heterodimeric complex of RAR and RXR ligandbinding domains. Mol Cell 2000, 5(2):289-298.

22. Rochel N, Wurtz JM, Mitschler A, Klaholz B, Moras D: The crystal structure of the nuclear receptor for vitamin $\mathrm{D}$ bound to its natural ligand. $\mathrm{Mol}$ Cell 2000, 5(1):173-179.

23. Wagner RL, Apriletti JW, McGrath ME, West BL, Baxter JD, Fletterick RJ: A structural role for hormone in the thyroid hormone receptor. Nature 1995, 378(6558):690-697.

24. Roeder RG: The role of general initiation factors in transcription by RNA polymerase II. Trends Biochem Sci 1996, 21(9):327-335.

25. Jin L, Li Y: Structural and functional insights into nuclear receptor signaling. Adv Drug Deliv Rev 2010, 62(13):1218-1226.

26. Heery DM, Kalkhoven E, Hoare S, Parker MG: A signature motif in transcriptional co-activators mediates binding to nuclear receptors. Nature 1997, 387(6634):733-736.

27. Torchia J, Rose DW, Inostroza J, Kamei Y, Westin S, Glass CK, Rosenfeld MG The transcriptional co-activator $\mathrm{p} / \mathrm{CIP}$ binds CBP and mediates nuclearreceptor function. Nature 1997, 387(6634):677-684.

28. Mclnerney EM, Rose DW, Flynn SE, Westin S, Mullen TM, Krones A, Inostroza J, Torchia J, Nolte RT, Assa-Munt N, et al: Determinants of coactivator LXXLL motif specificity in nuclear receptor transcriptional activation. Genes Dev 1998, 12(21):3357-3368.

29. Bulynko YA, O'Malley BW: Nuclear Receptor Coactivators: Structural and Functional Biochemistry. Biochemistry 2010, 2010:2010.

30. Chen JD: Steroid/nuclear receptor coactivators. Vitam Horm 2000, 58:391-448.

31. Chen S, Johnson BA, Li Y, Aster S, McKeever B, Mosley R, Moller DE, Zhou G: Both coactivator LXXLL motif-dependent and -independent interactions are required for peroxisome proliferator-activated receptor gamma (PPARgamma) function. J Biol Chem 2000, 275(6):3733-3736.

32. Vo N, Goodman RH: CREB-binding protein and $p 300$ in transcriptional regulation. J Biol Chem 2001, 276(17):13505-13508.

33. McKenna NJ, O'Malley BW: Minireview: nuclear receptor coactivators-an update. Endocrinology 2002, 143(7):2461-2465

34. Glass CK, Rose DW, Rosenfeld MG: Nuclear receptor coactivators. Curr Opin Cell Biol 1997, 9(2):222-232

35. Metivier R, Reid G, Gannon F: Transcription in four dimensions: nuclear receptor-directed initiation of gene expression. EMBO Rep 2006, 7(2):161 167

36. Fernandes I, White $\mathrm{JH}$ : Agonist-bound nuclear receptors: not just targets of coactivators. J Mol Endocrinol 2003, 31(1):1-7.

37. Surjit M, Ganti KP, Mukherji A, Ye T, Hua G, Metzger D, Li M, Chambon P. Widespread negative response elements mediate direct repression by agonist-liganded glucocorticoid receptor. Cell 2011, 145(2):224-241.

38. Oetting A, Yen PM: New insights into thyroid hormone action. Best Pract Res Clin Endocrinol Metab 2007, 21(2):193-208.

39. Ruan XZ, Varghese Z, Powis SH, Moorhead JF: Nuclear receptors and their coregulators in kidney. Kidney Int 2005, 68(6):2444-2461.

40. Johansson L, Bavner A, Thomsen JS, Farnegardh M, Gustafsson JA, Treuter E: The orphan nuclear receptor SHP utilizes conserved LXXLL-related motifs for interactions with ligand-activated estrogen receptors. Mol Cell Biol 2000, 20(4):1124-1133. 
41. Jimenez-Lara AM, Aranda A: Interaction of vitamin D and retinoid receptors on regulation of gene expression. Horm Res 2000, 54(5-6):301-305

42. Glass CK, Saijo K: Nuclear receptor transrepression pathways that regulate inflammation in macrophages and T cells. Nat Rev Immunol 2010, 10(5):365-376

43. Mundel P, Shankland SJ: Podocyte biology and response to injury. J Am Soc Nephrol 2002, 13(12):3005-3015.

44. Faul C, Asanuma K, Yanagida-Asanuma E, Kim K, Mundel P: Actin up: regulation of podocyte structure and function by components of the actin cytoskeleton. Trends Cell Biol 2007, 17(9):428-437.

45. Mundel P, Reiser J: Proteinuria: an enzymatic disease of the podocyte? Kidney Int 2010, 77(7):571-580.

46. Chuang PY, He JC: Signaling in regulation of podocyte phenotypes. Nephron Physio/ 2009, 111(2):p9-p15.

47. Kawachi H, Suzuki K, Miyauchi N, Hashimoto T, Otaki Y, Shimizu F: Slit diaphragm dysfunction in proteinuric states: identification of novel therapeutic targets for nephrotic syndrome. Clin Exp Nephrol 2009, 13(4):275-280

48. Kestila M, Lenkkeri U, Mannikko M, Lamerdin J, McCready P, Putaala H, Ruotsalainen V, Morita T, Nissinen M, Herva R, et al: Positionally cloned gene for a novel glomerular protein-nephrin-is mutated in congenital nephrotic syndrome. Mol Cell 1998, 1(4):575-582.

49. Putaala H, Soininen R, Kilpelainen P, Wartiovaara J, Tryggvason K: The murine nephrin gene is specifically expressed in kidney, brain and pancreas: inactivation of the gene leads to massive proteinuria and neonatal death. Hum Mol Genet 2001, 10(1):1-8.

50. Cooper ME, Mundel P, Boner G: Role of nephrin in renal disease including diabetic nephropathy. Semin Nephrol 2002, 22(5):393-398.

51. Dai S, Wang Z, Pan X, Wang W, Chen X, Ren H, Hao C, Han B, Chen N: Functional analysis of promoter mutations in the ACTN4 and SYNPO genes in focal segmental glomerulosclerosis. Nephrol Dial Transplant 2010, 25(3):824-835

52. Vinai M, Waber $P$, Seikaly MG: Recurrence of focal segmental glomerulosclerosis in renal allograft: an in-depth review. Pediatr Transplant 2010, 14(3):314-325.

53. Fernandez Fresnedo G, Sanchez Plumed J, Arias M, Del Castillo Caba D, Lopez Oliva MO: Progression factors in chronic kidney disease. Nonimmunological mechanisms. Nefrologia 2009, 29(Suppl 1):16-24.

54. Nagase M, Fujita T: Aldosterone and glomerular podocyte injury. Clin Exp Nephrol 2008, 12(4):233-242.

55. Kiyomoto H, Rafiq K, Mostofa M, Nishiyama A: Possible underlying mechanisms responsible for aldosterone and mineralocorticoid receptordependent renal injury. J Pharmacol Sci 2008, 108(4):399-405.

56. Ransom RF, Lam NG, Hallett MA, Atkinson SJ, Smoyer WE: Glucocorticoids protect and enhance recovery of cultured murine podocytes via actin filament stabilization. Kidney Int 2005, 68(6):2473-2483.

57. Benigni A, Zoja C, Campana M, Corna D, Sangalli F, Rottoli D, Gagliardini E, Conti S, Ledbetter S, Remuzzi G: Beneficial effect of TGFbeta antagonism in treating diabetic nephropathy depends on when treatment is started. Nephron Exp Nephrol 2006, 104(4):e158-e168.

58. Ren S, Xin C, Beck KF, Saleem MA, Mathieson P, Pavenstadt H, Pfeilschifter J, Huwiler A: PPARalpha activation upregulates nephrin expression in human embryonic kidney epithelial cells and podocytes by a dual mechanism. Biochem Biophys Res Commun 2005, 338(4):1818-1824.

59. Suzuki A, Ito T, Imai E, Yamato M, Iwatani H, Kawachi H, Hori M: Retinoids regulate the repairing process of the podocytes in puromycin aminonucleoside-induced nephrotic rats. J Am Soc Nephrol 2003, 14(4):981-991.

60. Fujii Y, Khoshnoodi J, Takenaka H, Hosoyamada M, Nakajo A, Bessho F, Kudo A, Takahashi S, Arimura Y, Yamada A, et al: The effect of dexamethasone on defective nephrin transport caused by ER stress: a potential mechanism for the therapeutic action of glucocorticoids in the acquired glomerular diseases. Kidney Int 2006, 69(8):1350-1359.

61. Kummer S, Jeruschke S, Wegerich LV, Peters A, Lehmann P, Seibt A, Mueller F, Koleganova N, Halbenz E, Schmitt CP, et al: Estrogen receptor alpha expression in podocytes mediates protection against apoptosis in-vitro and in-vivo. PLoS One 2011, 6(11):e27457.

62. Gross ML, Adamczak M, Rabe T, Harbi NA, Krtil J, Koch A, Hamar P, Amann K. Ritz E: Beneficial Effects of Estrogens on Indices of Renal Damage in Uninephrectomized SHRsp Rats. J Am Soc Nephrol 2004, 15(2):348-358.
63. Catanuto P, Doublier S, Lupia E, Fornoni A, Berho M, Karl M, Striker GE, Xia $X$, Elliot S: 17 beta-estradiol and tamoxifen upregulate estrogen receptor beta expression and control podocyte signaling pathways in a model of type 2 diabetes. Kidney Int 2009, 75(11):1194-1201.

64. Doublier S, Lupia E, Catanuto P, Periera-Simon S, Xia X, Korach K, Berho M, Elliot SJ, Karl M: Testosterone and 17beta-estradiol have opposite effects on podocyte apoptosis that precedes glomerulosclerosis in female estrogen receptor knockout mice. Kidney Int 2011, 79(4):404-413.

65. Xing CY, Saleem MA, Coward RJ, Ni L, Witherden IR, Mathieson PW: Direct effects of dexamethasone on human podocytes. Kidney Int 2006, 70(6):1038-1045.

66. Yamauchi K, Takano Y, Kasai A, Hayakawa K, Hiramatsu N, Enomoto N, Yao J, Kitamura M: Screening and identification of substances that regulate nephrin gene expression using engineered reporter podocytes. Kidney Int 2006, 70(5):892-900.

67. Wada T, Pippin JW, Nangaku M, Shankland SJ: Dexamethasone's prosurvival benefits in podocytes require extracellular signal-regulated kinase phosphorylation. Nephron Exp Nephrol 2008, 109(1):e8-e19.

68. Bertocchio JP, Warnock DG, Jaisser F: Mineralocorticoid receptor activation and blockade: an emerging paradigm in chronic kidney disease. Kidney Int 2011, 79(10):1051-1060.

69. Shibata S, Nagase M, Yoshida S, Kawachi H, Fujita T: Podocyte as the target for aldosterone: roles of oxidative stress and Sgk1. Hypertension 2007, 49(2):355-364

70. Nagai Y, Yao L, Kobori H, Miyata K, Ozawa Y, Miyatake A, Yukimura T, Shokoji T, Kimura S, Kiyomoto $H$, et al: Temporary angiotensin II blockade at the prediabetic stage attenuates the development of renal injury in type 2 diabetic rats. J Am Soc Nephrol 2005, 16(3):703-711.

71. Nagase M, Shibata S, Yoshida S, Nagase T, Gotoda T, Fujita T: Podocyte injury underlies the glomerulopathy of Dahl salt-hypertensive rats and is reversed by aldosterone blocker. Hypertension 2006, 47(6):1084-1093.

72. Nishiyama A, Kobori H, Konishi Y, Morikawa T, Maeda I, Okumura M, Kishida M, Hamada M, Nagai Y, Nakagawa T, et al: Mineralocorticoid receptor blockade enhances the antiproteinuric effect of an angiotensin II blocker through inhibiting podocyte injury in type 2 diabetic rats. J Pharmacol Exp Ther 2010, 332(3):1072-1080.

73. Schjoedt KJ, Andersen S, Rossing P, Tarnow L, Parving HH: Aldosterone escape during blockade of the renin-angiotensin-aldosterone system in diabetic nephropathy is associated with enhanced decline in glomerular filtration rate. Diabetologia 2004, 47(11):1936-1939.

74. Nagase M: Activation of the aldosterone/mineralocorticoid receptor system in chronic kidney disease and metabolic syndrome. Clin Exp Nephrol 2010, 14(4):303-314.

75. Portilla D, Dai G, Peters JM, Gonzalez FJ, Crew MD, Proia AD: Etomoxirinduced PPARalpha-modulated enzymes protect during acute renal failure. Am J Physiol Renal Physiol 2000, 278(4):F667-F675.

76. Sivarajah A, Chatterjee PK, Hattori Y, Brown PA, Stewart KN, Todorovic Z, Mota-Filipe $\mathrm{H}$, Thiemermann C: Agonists of peroxisome-proliferator activated receptor-alpha (clofibrate and WY14643) reduce renal ischemia/reperfusion injury in the rat. Med Sci Monit 2002, 8(12):BR532-BR539.

77. Zhou Y, Kong X, Zhao P, Yang H, Chen L, Miao J, Zhang X, Yang J, Ding J, Guan Y: Peroxisome proliferator-activated receptor-alpha is renoprotective in doxorubicin-induced glomerular injury. Kidney Int 2011, 79(12):1302-1311.

78. Mori K, Mukoyama M, Nakao K: PPAR-alpha transcriptional activity is required to combat doxorubicin-induced podocyte injury in mice. Kidney Int 2011, 79(12):1274-1276.

79. Lehmann JM, Moore LB, Smith-Oliver TA, Wilkison WO, Willson TM, Kliewer $\mathrm{SA}$ : An antidiabetic thiazolidinedione is a high affinity ligand for peroxisome proliferator-activated receptor gamma (PPAR gamma). J Biol Chem 1995, 270(22):12953-12956.

80. Sivarajah A, Chatterjee PK, Patel NS, Todorovic Z, Hattori Y, Brown PA, Stewart KN, Mota-Filipe H, Cuzzocrea S, Thiemermann C: Agonists of peroxisome-proliferator activated receptor-gamma reduce renal ischemia/reperfusion injury. Am J Nephrol 2003, 23(4):267-276.

81. Collino M, Patel NS, Lawrence KM, Collin M, Latchman DS, Yaqoob MM, Thiemermann C: The selective PPARgamma antagonist GW9662 reverses the protection of LPS in a model of renal ischemia-reperfusion. Kidney Int 2005, 68(2):529-536. 
82. Kanjanabuch T, Ma LJ, Chen J, Pozzi A, Guan Y, Mundel P, Fogo AB: PPARgamma agonist protects podocytes from injury. Kidney Int 2007, 71(12):1232-1239.

83. Mendelsohn C, Larkin S, Mark M, LeMeur M, Clifford J, Zelent A, Chambon P: RAR beta isoforms: distinct transcriptional control by retinoic acid and specific spatial patterns of promoter activity during mouse embryonic development. Mech Dev 1994, 45(3):227-241.

84. Mendelsohn C, Lohnes D, Decimo D, Lufkin T, LeMeur M, Chambon P, Mark M: Function of the retinoic acid receptors (RARs) during development (II). Multiple abnormalities at various stages of organogenesis in RAR double mutants. Development 1994, 120(10):2749-2771.

85. Moreno-Manzano V, Mampaso F, Sepulveda-Munoz JC, Alique M, Chen S, Ziyadeh FN, la Cruz MC I-d, Rodriguez J, Nieto E, Orellana JM, et al: Retinoids as a potential treatment for experimental puromycin-induced nephrosis. Br J Pharmacol 2003, 139(4):823-831.

86. Xu Q, Lucio-Cazana J, Kitamura M, Ruan X, Fine LG, Norman JT: Retinoids in nephrology: promises and pitfalls. Kidney Int 2004, 66(6):2119-2131.

87. He JC, Lu TC, Fleet M, Sunamoto M, Husain M, Fang W, Neves S, Chen Y, Shankland S, lyengar $R$, et al: Retinoic acid inhibits HIV-1-induced podocyte proliferation through the CAMP pathway. J Am Soc Nephrol 2007, 18(1):93-102.

88. Ratnam KK, Feng X, Chuang PY, Verma V, Lu TC, Wang J, Jin Y, Farias EF, Napoli JL, Chen N, et al: Role of the retinoic acid receptor-alpha in HIV-associated nephropathy. Kidney Int 2011, 79(6):624-634.

89. Zhong Y, Wu Y, Liu R, Li Z, Chen Y, Evans T, Chuang P, Das B, He JC: Novel retinoic acid receptor alpha agonists for treatment of kidney disease. PLoS One 2011, 6(11):e27945.

90. Vaughan MR, Pippin JW, Griffin SV, Krofft R, Fleet M, Haseley L, Shankland SJ: ATRA induces podocyte differentiation and alters nephrin and podocin expression in vitro and in vivo. Kidney Int 2005, 68(1):133-144.

91. Tan X, Li Y, Liu Y: Paricalcitol attenuates renal interstitial fibrosis in obstructive nephropathy. J Am Soc Nephrol 2006, 17(12):3382-3393.

92. Klaus G: Renoprotection with vitamin D: specific for diabetic nephropathy? Kidney Int 2008, 73(2):141-143.

93. Wang Y, Zhou J, Minto AW, Hack BK, Alexander JJ, Haas M, Li YC, Heilig CW, Quigg RJ: Altered vitamin D metabolism in type II diabetic mouse glomeruli may provide protection from diabetic nephropathy. Kidney Int 2006, 70(5):882-891.

94. Deb DK, Wang Y, Zhang Z, Nie H, Huang X, Yuan Z, Chen Y, Zhao Q, Li YC: Molecular mechanism underlying 1,25-dihydroxyvitamin $D$ regulation of nephrin gene expression. J Biol Chem 2011, 286(37):32011-32017.

95. Zhang Z, Sun L, Wang Y, Ning G, Minto AW, Kong J, Quigg RJ, Li YC Renoprotective role of the vitamin $D$ receptor in diabetic nephropathy. Kidney Int 2008, 73(2):163-171.

96. Bertocchio JP, Jaisser F: Aldosterone and kidney diseases: an emergent paradigm with important clinical implications. Nephrol Ther 2011, 7(3):139-147.

97. Briet M, Schiffrin EL: Aldosterone: effects on the kidney and cardiovascular system. Nat Rev Nephrol 2010, 6(5):261-273.

98. Greene EL, Kren S, Hostetter TH: Role of aldosterone in the remnant kidney model in the rat. J Clin Invest 1996, 98(4):1063-1068.

99. Nishiyama A, Yoshizumi M, Rahman M, Kobori H, Seth DM, Miyatake A, Zhang GX, Yao L, Hitomi H, Shokoji T, et al: Effects of AT1 receptor blockade on renal injury and mitogen-activated protein activity in Dahl salt-sensitive rats. Kidney Int 2004, 65(3):972-981.

100. Sun GP, Kohno M, Guo P, Nagai Y, Miyata K, Fan YY, Kimura S, Kiyomoto H, Ohmori K, Li DT, et al: Involvements of Rho-kinase and TGF-beta pathways in aldosterone-induced renal injury. J Am Soc Nephrol 2006, 17(8):2193-2201.

101. Yaoita E, Kawasaki K, Yamamoto T, Kihara I: Variable expression of desmin in rat glomerular epithelial cells. Am J Pathol 1990, 136(4): 899-908.

102. Yan K, Kudo A, Hirano H, Watanabe T, Tasaka T, Kataoka S, Nakajima N, Nishibori Y, Shibata T, Kohsaka T, et al: Subcellular localization of glucocorticoid receptor protein in the human kidney glomerulus. Kidney Int 1999, 56(1):65-73.

103. Guess A, Agrawal S, Wei CC, Ransom RF, Benndorf R, Smoyer WE: Doseand time-dependent glucocorticoid receptor signaling in podocytes. Am J Physiol Renal Physiol 2010, 299(4):F845-F853.

104. Michalik L, Auwerx J, Berger JP, Chatterjee VK, Glass CK, Gonzalez FJ, Grimaldi PA, Kadowaki T, Lazar MA, O'Rahilly S, et al: International Union of
Pharmacology. LXI. Peroxisome proliferator-activated receptors. Pharmacol Rev 2006, 58(4):726-741.

105. Boulanger H, Mansouri R, Gautier JF, Glotz D: Are peroxisome proliferatoractivated receptors new therapeutic targets in diabetic and non-diabetic nephropathies? Nephrol Dial Transplant 2006, 21(10):2696-2702.

106. Ruan X, Zheng F, Guan Y: PPARs and the kidney in metabolic syndrome. Am J Physiol Renal Physiol 2008, 294(5):F1032-F1047.

107. Letavernier E, Perez J, Joye E, Bellocq A, Fouqueray B, Haymann JP, Heudes D, Wahli W, Desvergne B, Baud L: Peroxisome proliferator-activated receptor beta/delta exerts a strong protection from ischemic acute renal failure. J Am Soc Nephrol 2005, 16(8):2395-2402.

108. Staels B, Koenig W, Habib A, Merval R, Lebret M, Torra IP, Delerive P, Fadel $A$, Chinetti G, Fruchart JC, et al: Activation of human aortic smooth-muscle cells is inhibited by PPARalpha but not by PPARgamma activators. Nature 1998, 393(6687):790-793.

109. Inoue $H$, Tanabe T: Transcriptional role of the nuclear factor kappa B site in the induction by lipopolysaccharide and suppression by dexamethasone of cyclooxygenase-2 in U937 cells. Biochem Biophys Res Commun 1998, 244(1):143-148.

110. Delerive P, De Bosscher K, Besnard S, Vanden Berghe W, Peters JM, Gonzalez FJ, Fruchart JC, Tedgui A, Haegeman G, Staels B: Peroxisome proliferatoractivated receptor alpha negatively regulates the vascular inflammatory gene response by negative cross-talk with transcription factors NFkappaB and AP-1. J Biol Chem 1999, 274(45):32048-32054.

111. Kam RK, Deng Y, Chen Y, Zhao H: Retinoic acid synthesis and functions in early embryonic development. Cell Biosci 2012, 2(1):11

112. Okamura M, Takano Y, Saito Y, Yao J, Kitamura M: Induction of nephrin gene expression by selective cooperation of the retinoic acid receptor and the vitamin D receptor. Nephrol Dial Transplant 2009, 24(10):3006-3012.

113. Han SY, So GA, Jee YH, Han KH, Kang YS, Kim HK, Kang SW, Han DS, Han JY, Cha DR: Effect of retinoic acid in experimental diabetic nephropathy. Immunol Cell Biol 2004, 82(6):568-576.

114. Morath C, Dechow C, Lehrke I, Haxsen V, Waldherr R, Floege J, Ritz E, Wagner J: Effects of retinoids on the TGF-beta system and extracellular matrix in experimental glomerulonephritis. J Am Soc Nephrol 2001, 12(11):2300-2309.

115. Simonson MS: Anti-AP-1 activity of all-trans retinoic acid in glomerular mesangial cells. Am J Physiol 1994, 267(5 Pt 2):F805-F815.

116. Na SY, Kang BY, Chung SW, Han SJ, Ma X, Trinchieri G, Im SY, Lee JW, Kim TS: Retinoids inhibit interleukin-12 production in macrophages through physical associations of retinoid $\mathrm{X}$ receptor and NFkappaB. J Biol Chem 1999, 274(12):7674-7680.

117. Chonchol M, Cigolini M, Targher G: Association between 25hydroxyvitamin D deficiency and cardiovascular disease in type 2 diabetic patients with mild kidney dysfunction. Nephrol Dial Transplant 2008, 23(1):269-274.

118. Hypponen E, Laara E, Reunanen A, Jarvelin MR, Virtanen SM: Intake of vitamin D and risk of type 1 diabetes: a birth-cohort study. Lancet 2001, 358(9292):1500-1503.

119. Levin A, Bakris GL, Molitch M, Smulders M, Tian J, Williams LA, Andress DL: Prevalence of abnormal serum vitamin D, PTH, calcium, and phosphorus in patients with chronic kidney disease: results of the study to evaluate early kidney disease. Kidney Int 2007, 71(1):31-38.

120. Zehnder D, Quinkler M, Eardley KS, Bland R, Lepenies J, Hughes SV, Raymond NT, Howie AJ, Cockwell P, Stewart PM, et al: Reduction of the vitamin $D$ hormonal system in kidney disease is associated with increased renal inflammation. Kidney Int 2008, 74(10):1343-1353.

121. Tian J, Wang HP, Mao YY, Jin J, Chen JH: Reduced glomerular epithelial protein 1 expression and podocyte injury in immunoglobulin $\mathrm{A}$ nephropathy. J Int Med Res 2007, 35(3):338-345.

122. Reis JP, Loria CM, Sorlie PD, Park Y, Hollenbeck A, Schatzkin A: Lifestyle factors and risk for new-onset diabetes: a population-based cohort study. Ann Intern Med 2011, 155(5):292-299.

123. Li D, Ding J: Molecular mechanism of proteinuria caused progression of chronic renal disease. Beijing Da Xue Xue Bao 2010, 42(5):608-611.

124. Branisteanu DD, Leenaerts $P$, van Damme B, Bouillon R: Partial prevention of active Heymann nephritis by 1 alpha, 25 dihydroxyvitamin D3. Clin Exp Immunol 1993, 94(3):412-417

125. Makibayashi K, Tatematsu M, Hirata M, Fukushima N, Kusano K, Ohashi S, Abe H, Kuze K, Fukatsu A, Kita T, et al: A vitamin D analog ameliorates 
glomerular injury on rat glomerulonephritis. Am J Pathol 2001, 158(5):1733-1741.

126. Migliori M, Giovannini L, Panichi V, Filippi C, Taccola D, Origlia N, Mannari C, Camussi G: Treatment with 1,25-dihydroxyvitamin D3 preserves glomerular slit diaphragm-associated protein expression in experimental glomerulonephritis. Int J Immunopathol Pharmacol 2005, 18(4):779-790.

127. Panichi V, Migliori M, Taccola D, Filippi C, De Nisco L, Giovannini L, Palla R, Tetta C, Camussi G: Effects of 1,25(OH)2D3 in experimental mesangial proliferative nephritis in rats. Kidney Int 2001, 60(1):87-95.

128. Kuhlmann A, Haas CS, Gross ML, Reulbach U, Holzinger M, Schwarz U, Ritz E, Amann K: 1,25-Dihydroxyvitamin D3 decreases podocyte loss and podocyte hypertrophy in the subtotally nephrectomized rat. Am J Physiol Renal Physiol 2004, 286(3):F526-F533.

129. Schwarz U, Amann K, Orth SR, Simonaviciene A, Wessels S, Ritz E: Effect of $1,25(\mathrm{OH}) 2$ vitamin $\mathrm{D} 3$ on glomerulosclerosis in subtotally nephrectomized rats. Kidney Int 1998, 53(6):1696-1705.

130. Zou MS, Yu J, Nie GM, He WS, Luo LM, Xu HT: 1, 25-dihydroxyvitamin D3 decreases adriamycin-induced podocyte apoptosis and loss. Int J Med Sci 2010, 7(5):290-299.

131. Zou MS, Yu J, Zhou JH, Nie GM, Ding DS, Luo LM, Xu HT, He WS: 1,25-Dihydroxyvitamin D3 ameliorates podocytopenia in rats with adriamycin-induced nephropathy. Intern Med 2010, 49(24):2677-2686.

132. Sanchez-Nino MD, Bozic M, Cordoba-Lanus E, Valcheva P, Gracia O, Ibarz M, Fernandez E, Navarro-Gonzalez JF, Ortiz A, Valdivielso JM: Beyond proteinuria: VDR activation reduces renal inflammation in experimental diabetic nephropathy. Am J Physiol Renal Physiol 2012, 302(6):F647-F657.

133. Zhang Z, Yuan W, Sun L, Szeto FL, Wong KE, Li X, Kong J, Li YC: 1,25-Dihydroxyvitamin D3 targeting of NF-kappaB suppresses high glucose-induced MCP-1 expression in mesangial cells. Kidney Int 2007, 72(2):193-201.

134. Stumpf WE, Sar M, Reid FA, Tanaka Y, DeLuca HF: Target cells for 1,25-dihydroxyvitamin D3 in intestinal tract, stomach, kidney, skin, pituitary, and parathyroid. Science 1979, 206(4423):1188-1190.

135. Deb DK, Chen Y, Zhang Z, Zhang Y, Szeto FL, Wong KE, Kong J, Li YC: 1,25-Dihydroxyvitamin D3 suppresses high glucose-induced angiotensinogen expression in kidney cells by blocking the NF-\{kappa\}B pathway. Am J Physiol Renal Physiol 2009, 296(5):F1212-F1218.

136. Takano Y, Yamauchi K, Hiramatsu N, Kasai A, Hayakawa K, Yokouchi M, Yao J, Kitamura M: Recovery and maintenance of nephrin expression in cultured podocytes and identification of HGF as a repressor of nephrin. Am J Physiol Renal Physiol 2007, 292(5):F1573-F1582.

137. Kim JE, Chen J: regulation of peroxisome proliferator-activated receptorgamma activity by mammalian target of rapamycin and amino acids in adipogenesis. Diabetes 2004, 53(11):2748-2756.

138. Finn AV, John M, Nakazawa G, Polavarapu R, Karmali V, Xu X, Cheng Q, Davis T, Raghunathan C, Acampado E, et al: Differential healing after sirolimus, paclitaxel, and bare metal stent placement in combination with peroxisome proliferator-activator receptor gamma agonists: requirement for mTOR/Akt2 in PPARgamma activation. Circ Res 2009, 105(10):1003-1012.

doi:10.1186/2045-3701-2-33

Cite this article as: Khurana et al: Nuclear hormone receptors in podocytes. Cell \& Bioscience 2012 2:33.

\section{Submit your next manuscript to BioMed Central and take full advantage of:}

- Convenient online submission

- Thorough peer review

- No space constraints or color figure charges

- Immediate publication on acceptance

- Inclusion in PubMed, CAS, Scopus and Google Scholar

- Research which is freely available for redistribution 